\title{
Book review: Virginia Costa, Modern Metals in Cultural Heritage, understanding and characterization, Getty Conservation Institute, Los Angeles, 2019, 136 p.
}

ISABEL TISSOT

LIBPhys-UNL, Departamento de Física, Universidade NOVA de Lisboa, Caparica, Portugal isabeltissot@gmail.com

\author{
Revisão de Livro: Virginia Costa, Modern \\ Metals in Cultural Heritage, understanding and \\ characterization, Getty Conservation Institute, \\ Los Angeles, 2019, 136 p.
}

The conservation of modern metals-such as aluminium, stainless, and weathering steels-used as materials of contemporary works of art is a major challenge for conservators and curators. The recent application of these metals, in use since the beginning of the nineteenth century, makes for the lack of conservative measurements and conservation programs on such materials.

In order to achieve this, a detailed identification, characterisation of the fabrication techniques, and the study of these metals' deterioration is required. In her book, Virginia Costa embraces the hard challenge of bridging this gap.

Virginia Costa proposes to "provide basic knowledge to professionals dealing with modern metals" and to attain this, Costa structured the book in three parts with eleven chapters. The first part considers basic concepts of metals and alloys-nature, properties, and characterisation. The second part includes a description of a selected set of metal alloys detailing the metallurgical background, designation, properties and applications, deterioration, characterisation, and conservation-related literature. The last part is devoted to surface coatings and includes the description of the main metallic and conversion coatings processes. The book ends with a glossary of key terms.

Chapters 1 and 2 of the first part of the book are very detailed, written in a clear and accessible language for nonexperts in material science. Furthermore, these chapters, as well as all others, are extremely well illustrated, which constitutes one of the book strengths. The illustrations and schemes are well thought and executed. The third chapter, dedicated to the characterisation of metals and to their conservation condition, is brief and has some incomplete parts. The chapter is divided into visual inspection and analysis, however, some imperative exams and analysis currently used for characterisation of metals and their deterioration [1], such as X-ray diffraction and radiography are missing. Nonetheless, radiography is used to illustrate manufacturing methods in later chapters.

Metallic alloys are considered in the second part of the book. Virginia Costa focus on aluminium alloys, copper alloys, stainless steels, titanium alloys, weathering steels, and zinc alloys. The metallurgical background, designation, properties, and applications, are clearly described and illustrated. The exercise of summarizing the deterioration description and the metals characterisation is complex, and, for some of the selected metals it would be important to detail them, e.g. the visual characterisation of corroded copper alloys (p. 73). However, Virginia Costa always adds references allowing to complete and detail the information. The conservation related literature although not exhaustive, covers wide situations of the use and alteration of the mentioned metals.

The last part of the book is devoted to surface coatings (metallic and conversion). Chapter 10 considers the description of processes such as electroplating (continuous plating, brush plating, alloy plating, plating on plastics, electroforming), electroless plating, and hot dipping (zinc hot dipping, hotdip tinning, lead-alloy hot dipping, aluminium hot dipping). Chapter 11 approaches conversion coatings namely anodizing, chromate conversion coatings, and phosphate conversion coatings. The processes explanation is followed by a brief description of the structures, properties, and the coatings application. The processes description is succinct but clear and the examples of the applications well illustrated. 
This book is certainly a valuable addition to the bookshelves of metal conservators and curators, and a useful foundation for conservation students, in their first contact with these areas.

\section{References}

1. Neff, D; Reguer, S.; Dillman, P., 'Analytical techniques for the study of corrosion of metallic heritage artefacts: from micrometer to nanometer scales', in Corrosion and conservation of cultural heritage metallic artefacts, ed. P. Dillmann, D. Watkinson, E. Angelini and A. Adriaens, Woodhead Publishing in Materials, Cambridge (2013) 55-82.
RECEBIDO: 2019.8.7

ACEITE: 2019.8 .9

ONLINE: 2020.4 .15

\section{@(1) $\Theta$}

This work is licensed under the Creative Commons

Attribution-NonCommercial-NoDerivatives 4.0 International License. To view a copy of this license, visit

http://creativecommons.org/licenses/by-nc-nd/4.o/deed.en. 